\title{
La novela de Cervantes y las primeras novelas picarescas*
}

\section{Cervantes' novels and the first picaresque novels}

\author{
Juan Ramón Muñoz Sánchez \\ Università degli Studi di Torino
}

RESUMEN: Partiendo de la doble premisa de que Cervantes fue a un tiempo escritor y crítico literario y de que tenía una portentosa consciencia genérica, que le llevaba a sondear metadiscursivamente la historicidad de los géneros con los que trabajaba y contra los que reaccionaba, en el presente artículo se define su concepción de la novela destacando sus características más significativas; se examina individualmente cada texto, haciendo hincapié en la génesis y evolución del género al que se afilia, y se la confronta con la novela picaresca con el propósito de analizar la posición del autor frente a la poética del género en su fase de institucionalización.

Palabras clave: género, novela picaresca, metadiscurso, historicidad, autodiégesis, verdad poética.

ABSTRACT: Starting from the double premises that Cervantes was both a writer and a literary critic with portentous knowledge of the literary genres -which led him to examine the historicity of the genres he worked with on a meta-discursive level- the article at hand defines his concept of the novel by highlighting its most significant features. Each novel is scrutinized individually, emphasizing on the origin and evolution of the genre which it is associated to, by contrasting it to the picaresque novel in order to analyse Cervantes' position in regard to the poetics of the picaresque genre during its institutional phase.

Keywords: genre, picaresque novel, meta-discourse, historicity, autodiegetic, poetic truth.

* La preparación de este trabajo se ha realizado al amparo del Ministerio de Educación, mediante el Programa Nacional de Movilidad de Recursos Humanos del Plan Nacional de I-D+i 2008-2011. 


\section{LA NOVELA DE CERVANTES: ENTRE CREACIÓN Y METACRÍTICA}

Decía Edward C. Riley (1998: CXXIX) que "hay escritores, hay críticos y hay escritores-críticos", para concluir que "Cervantes fue uno de estos últimos". $\mathrm{Y}$ efectivamente el malogrado cervantista, tal vez el principal investigador de su teoría de la novela ${ }^{1}$, tenía sobrada razón. Cervantes, "raro inventor", fue por encima de todo un estupendo forjador de mundos poéticos, tan libres y autónomos cuanto ambiguos e irónicos: "yo soy aquel que en la invención excede / a muchos", aseguraba de sí en el Viaje del parnaso (IV, vv. 28-29, p. 82). Mas era también un avezado lector, un competente conocedor de la literatura antigua y moderna, así de creación como de preceptiva, en latín, en italiano y en castellano. Sus textos, que mantienen un fecundo diálogo intertextual con la tradición heredada no menos que con las coordenadas literarias de su tiempo, así como sus personajes, siempre sedientos de ficción, lo corroboran con creces.

De suerte que en su obra se funden y confunden la historia y la poesía, se eliminan las fronteras que separan la vida y la literatura y se entreveran la teoría, la práctica y la reflexión literarias. Pero siempre desde el campo de la imaginación. Porque ciertamente nuestro autor no mostró interés alguno por compilar separadamente de la creación, y como elemento diegético de primer orden, sus muchos asertos diseminados a lo largo y ancho de su obra atinentes a la retórica, la estética, la poética y la historia de la literatura. Resulta imposible, por ello, discernir nítidamente si sus sorprendentes aciertos responden a una meditación, bien sobre el hecho literario, bien sobre su propio quehacer poético, bien sobre ambos factores a la vez. Pues lo que es evidente y significativo es que su intención no fue nunca la de conformar un recetario de doctrina literaria, sino, por el contrario, como "quien se atreve a salir con tantas invenciones a la plaza del mundo" (Novelas ejemplares, 16), la de abrir "un camino / por do la lengua castellana pueda / mostrar con propiedad un desatino" (Viaje del Parnaso, IV, vv. 25-27, p. 82), o, dicho con las palabras de uno de sus autores clásicos preferidos, Luciano de Samósata, contar "mentiras de todos los colores ["pseúsmata poikíla"] de modo convincente y verosímil" (Relatos verídicos, p. 179). Es decir: la de reivindicar un espacio privilegiado para la literatura como ficción, entretenimiento y conocimiento. Así, por caso, el licenciado Vidriera "admiraba y reverenciaba la ciencia de la poesía, porque encerraba en sí todas las demás ciencias, porque de todas se sirve, de todas se adorna y pule, y saca a luz sus maravillosas obras, con que llena el mundo de provecho, de deleite y de maravilla" (Licenciado Vidriera, p. 282).

1 Cfr. Riley (1973, 1989, 2000: 80-91). Sobre los fundamentos poéticos de Cervantes vid. igualmente Forcione (1970), Gilman (1993), Martínez Bonati (1995), Paz Gago (1995), Blasco (2005), Garrido Domínguez (2007), Pérez de León (2010). 
Es así como, en efecto, y antes que nadie, mas naturalmente en coalescencia con su contexto inmediato, dominado por el éxito del Guzmán de Alfarache y por la eclosión de la novela helenística, entendida por la preceptiva neoaristotélica como épica amorosa en prosa, así como con una tradición que se remonta a La Celestina y el Lazarillo, a la moria erasmiana y al humanismo cristiano, Cervantes elaboró desde la praxis una idea de la literatura entendida como un proceso lúdico de conocimiento: una mentira que esconde una verdad, cuyas claves no son otras que la intersubjetividad, la heteroglosia, la narratividad, la autorreferencialidad, el humor y la intratextualidad.

La consciencia analítica de Cervantes, inseparable de su labor de creación imaginativa, lleva aparejada una portentosa consciencia genérica. Ya Vicente de los Ríos, en su excelente "Análisis del Quijote", que sirvió de frontispicio a la edición del texto de la RAE de 1780, adivinaba con finura y agudeza que Cervantes en su máxima obra había fundido con verosimilitud dos tipos diferentes y aun contrapuestos de novela en una sola, que él denomina "épica burlesca" pero que finalmente ha dado en llamarse "novela moderna". De forma que para Vicente de los Ríos Cervantes no sólo conocía la diferencia existente entre las dos grandes variantes de la prosa de ficción, el "romance" y la "novela", sino también que, en función de la monomanía literaria del héroe, había encajado un libro de caballerías en el seno de una novela "realista". Esto es, había caído en la cuenta de que Cervantes, de acuerdo con Riley (2000: 21), "no habría podido escribir nunca el Quijote si no hubiera conocido la diferencia entre lo que hoy llamamos "novela' y romance"3. Y, efectivamente, Cervantes, a lo largo de su carrera de escritor, jugó y experimentó con sendas modalidades narrativas, se aproximó ya a una, la poesía, para mudar a la otra, la poética historia, como bautizó Mateo Alemán a su Guzmán de Alfarache (1599$1604)^{4}$, si no es que las combinó en fructífera dialéctica.

De hecho, una de sus más relevantes punterías, a contrapelo del neoaristotelismo reinante, fue la de ganar para la novela el territorio de la inverosimilitud verosímil: "mostrar con propiedad un desatino", porque, como escribirá siglos más tarde Thomas Mann, en su estupenda novela Carlota en Weimar (2006: 395), "sólo en el juego y en la ópera de magia está la salvación". Cervantes descubrió que el

2 "En la fábula de Cervantes — decía - cada aventura tiene dos aspectos muy distintos respecto al héroe y al lector. Éste no ve más que un suceso casual y ordinario en lo que para Don Quijote es una cosa rara y extraordinaria, que su imaginación le pinta con todos los colores de su locura (...). Así, en cada aventura hay por lo regular dos obstáculos y dos éxitos: uno efectivo en la realidad, y otro aparente en la aprensión de Don Quijote, y ambos naturales, deducidos de la acción, y verosímiles, sin embargo de ser opuestos" (Ríos, 2006: 282-283).

${ }^{3}$ Cfr. también su fundamental estudio Riley (2001a: 185-202). Vid. además, Sobejano (1978) y Gilman (1993: 15-58).

${ }^{4}$ Vid. Micó (1987: 25-56), Rodríguez (2001: 230-241), Ruffinatto (2000: 251-75). 
principio poético de la verosimilitud no descansa en factores externos al texto, como tampoco en su comparación mimética con la realidad del lector, sino en una serie de estrategias y normas internas de la propia obra: la ironía, la infidencia, el distanciamiento, la ambigüedad, la gradación, el perspectivismo..., y, sobre todo, en un pacto de fe y confianza entre el escritor y el lector, entre el poder de persuasión del primero y la receptividad del segundo, que tensó al límite en el par $E l$ casamiento engañoso-El coloquios de los perros y en el Persiles. De manera que los textos cervantinos en prosa, aun cuando se ajusten estrechamente a una región imaginativa específica, no pertenecen puntualmente a ninguna de ellas, dado que desbordan sus cauces genéricos. Esto es especialmente notorio tanto en el Quijote como en la Novelas ejemplares, conforme a su radical originalidad. Pero también, aunque en menor grado, en La Galatea y la Historia setentrional. Lo cual, desde luego, no significa que Cervantes no estuviera preocupado por la clasificación literaria y la definición de los distintos tipos y especies; antes bien, es una de sus obsesiones, tanto más cuanto que refulge por ser un rastreador incansable y concienzudo de la génesis y evolución de todos ellos.

En efecto, Cervantes indagaba metadiscursivamente en sus textos tanto la historicidad de los géneros a los que se afilian como la de aquellos con los que se relacionan dialécticamente. Y eso es precisamente lo que analizaremos en las páginas que siguen. Primero en La Galatea y el Persiles, donde se escruta la génesis y evolución del módulo pastoril así como de la épica amorosa en prosa; haciendo especial énfasis en la autodiégesis de Periandro, por cuanto, a través de ella, el autor enjuicia críticamente la primera persona narrativa desde el relato de viajes. Después, tras la confrontación de la novela picaresca con la novela de Cervantes con el propósito de considerar la posición del autor frente a la poética común del género, se hace lo propio en el Quijote y en las Novelas ejemplares respecto de los libros de caballerías y el género picaresco.

\section{LA Galatea y LoS tRabajos de PERSILES Y SIGISMUNDA}

Cervantes se estrena en 1585 en el mundo de las letras de molde, como es sabido, con una novela pastoril, La Galatea, y se despide con una novela de amor y aventuras, Los trabajos de Persiles y Sigismunda, publicada póstumamente en 1617. En realidad estos textos son las dos únicas incursiones de nuestro autor en el campo del "romance", aun cuando algunas de las Ejemplares se alleguen a sus parámetros, dado que la novela corta por lo general entraña una ilusión óptica de realidad comprobable, consigna la vida en curso y la relatividad de la verdad. No deja de ser curioso que el cultivo de tales moldes genéricos por parte de Cervantes esté en una relación inversamente proporcional, descendente el bucolismo, ascendente el "romance" de tipo griego, por mucho 
que siguiera prometiendo la continuación de La Galatea en los liminares de la Historia setentrional. Dado que después de haber escrito una novela pastoril ya no volvió a enfrascarse en el mundo de los pastores y sus cosas si no fue como episodio intercalado en sus narraciones de largo aliento, como un lance aislado o como un proyecto de vida en ciernes. A la novela bizantina, por el contrario, le prestó atención primero como historia lateral, luego como el patrón morfológico dominante de algunas de sus novelas cortas, hasta desembocar, por fin, en su publicación como un texto de largo alcance. La razón de ello no es otra que la peculiar evolución que experimentaron los géneros nacidos en el Renacimiento español, de los que sólo la novela pastoril se convirtió en género rápidamente; mientras que los otros, la novela bizantina, la picaresca y la morisca, en cambio, hubieron de esperar hasta el ocaso del siglo y el amanecer del siguiente para alcanzar carta de naturaleza. De suerte que Cervantes escribió sus dos textos al calor del éxito de cada modalidad. Es decir, por ocasión, por competición y por vanguardia literaria: tres factores que serán claves en todas las publicaciones novelescas de Cervantes.

Como todo escritor que sigue un modelo, Cervantes conocía bien el género en que se adentraba tanto con La Galatea como con Los trabajos de Persiles y Sigismunda. Así las cosas, no es mucho que a la primera la tache de "libro de poesía", debido a su característica mescolanza de prosa y verso, en el donoso escrutinio de la biblioteca de don Quijote (I, VI, p. 78), y a la otra como épica en prosa, "que la épica — concluye el Canónigo de Toledo - tan bien puede escrebirse en prosa como en verso" (Don Quijote, I, XLVII, p. 504). Más relevante es que en el Prólogo a los curiosos lectores de su obra primeriza denominase "égloga" (La Galatea, p. 16) a la novela pastoril, pues eso significa que Cervantes estaba al tanto de que el género provenía en derechura de las Bucólicas (c. 37 a. C.) de Virgilio, al tiempo que rendía tributo a su poeta español preferido, Garcilaso de la Vega. Además, en el famoso escrutinio, Cervantes esbozaba por boca del cura el itinerario histórico-literario de la novela pastoril: no en vano sostenía que La Diana de Montemayor tenía "la honra de ser primero en semejantes libros" (Don Quijote, I, VI, p. 79), al que imita de manera interesada en el comienzo de su pastoral. Por otro lado, era sobradamente consciente, libros de poesía los ha llamado, de que era una modalidad "romancesca" o de realismo estilizado, como se echa de ver tanto en que el cura Pero Pérez diga que "son libros de entretenimiento sin perjuicio de terceros", como, sobre todo, en la desmitificación que de ellos efectúa Berganza en El coloquio de los perros (p. 555): “cosas soñadas y bien escritas para entretenimiento de ociosos, y no verdad alguna" . Más aún: demostraba en la praxis que la cristalización de

\footnotetext{
${ }^{5}$ Ya en el capítulo XXVII de la primera parte del Quijote, al escuchar el cura y el barbero, mientras esperaban a que Sancho sacara a su amo de las entrañas de la Sierra Morena, una voz
} 
la novela pastoril se había ido fraguando en el seno de los libros de caballerías, a partir del tímido conato de bucolismo que supone la penitencia amorosa de Amadís, bajo el seudónimo de Beltenebros, en la Ínsola de la Peña Pobre, en el Amadís de Gaula (1508) de Garci Rodríguez de Montalvo, hasta lograr la mayoría de edad con el texto de Montemayor, al utilizar como subtexto la trama del Amadís en La Galatea (cfr. Muñoz Sánchez, 2004). Así como por el hecho de que una vez finiquitada la aventura caballeresca de don Quijote, tras su derrota en la marina de Barcelona a manos del Caballero de la Blanca Luna, Sancho, que se ha ido replegando a la fantasía de su señor, le proponga fingirse pastores. Tanto más cuanto que en uno de sus primeros ensayos dramáticos, $\mathrm{La}$ casa de los celos, conformaba su estructura sobre dos tramas paralelas, una caballeresca, la otra pastoril, que sin embargo confluían irónicamente en varios puntos. Conviene subrayar, por fin, que en La Galatea se produce un desplazamiento del "idealismo" genético del género hacia el 'realismo', en el punto y hora en que la historia, las convenciones sociopolíticas de la época y las tensiones entre los varios reinos peninsulares irrumpen con fuerza en el ámbito del mito, pues afectan dolorosamente a las pasiones de los pastores, que, obligados por las circunstancias, han de abandonar su esencia poética para adentrarse en el árido terreno de la realidad contingente.

Los trabajos de Persiles y Sigismunda, historia setentrional es el texto que el escritor complutense promocionó con mayor ahínco y entusiasmo, puesto que pensaba que sería la cumbre de su obra narrativa, aquella que le daría mayor fama y honra literarias. Es posible, y aun probable, que la primera manifestación del Persiles, si bien más como proyecto futuro que como realidad presente, fuera la descripción de la "novela ideal" que esboza el religioso toledano en el Quijote. Principalmente por la conclusión a la que llega de que la épica puede escribirse igualmente en prosa que en verso. Pues ese es, según la poética del escritor y la de su época, el género al que se adscribiría su postrera obra. Así, Cervantes, la primera vez que lo menciona, en el Prólogo al lector de las Novelas ejemplares (Cervantes, 2001: 19-20), subraya con provocación y desafío que su libro "se atreve a competir con Heliodoro, si ya por atrevido no sale con las manos en la cabeza". Esto es: con el autor paradigmático de la novela helenística, quien, con su elegante Historia etiópica, había hecho y hacía (la traducción de Fernando de Mena de 1584 se reimprimió sucesivamente en 1614, 1615 y 1616) las delicias de los preceptistas, moralistas, escritores y público lector de entonces; al tiempo que había abierto, para la modernidad literaria, la senda por la cual reconducir el libro de entretenimiento entendido

que llegó a sus oídos atípica por su dulzura del lugar, comenta el narrador: "Porque aunque suele decirse que por las selvas y campos se hallan pastores de voces estremadas, mas son encarecimientos de poetas que verdades" (Don Quijote, I, XXVII, p. 279). 
como épica amorosa. Y efectivamente como libro de entretenimiento es como denomina Cervantes al Persiles en los prolegómenos de la segunda parte del Quijote (p. 556): "el cual ha de ser — dice—o el más malo o el mejor que en nuestra lengua se haya compuesto, quiero decir de los de entretenimiento; y digo que me arrepiento de haber dicho malo, porque según la opinión de mis amigos ha de llegar al estremo de bondad". Lo cual no es más que una defensa a ultranza de la literatura como ficción, como "un engaño sin daño de barras".

Esta vez, Cervantes no establece el canon de la novela bizantina, sino que, fuera de la mención a Heliodoro, lo silencia. Pero, a cambio, lo marca ejemplarmente a lo largo de su obra. Ello se debe a que, aparte de las Etiópicas, rivaliza elocuentemente a la sorda con El peregrino en su patria (1604) de Lope de Vega. Cervantes había leído seguro la Selva de aventuras (1565-1583) de Jerónimo de Contreras, de la que hay alguna reminiscencia en el desenlace del Persiles y antes, en algún que otro relato episódico; y tal vez el Clareo y Florisea de Reinoso, por aquello de la geografía insular, pese a que sólo tuvo su edición veneciana de 1552. Más allá del texto de Heliodoro, conoció la otra novela de tipo griego, de las cinco conservadas, que se difundió en la Península durante los siglos XVI y XVII, a saber: el Leucipa y Clitofonte (siglo II) de Aquiles Tacio, del que, además de algún episodio aislado, como el conflicto inicial, y de algún detalle, como el truco amoroso de la abeja y el beso que emula en Los baños de Argel, Cervantes pudo tener en cuenta el tono cómico, a ratos casi paródico, la ironía, el realismo y la distancia con que Aquiles Tacio presenta lo narrado.

Es muy probable, por otro lado, que Cervantes notara que las aventuras sin cuento de los enamorados protagonistas de la bizantina podrían ser la alquitara en la que destilar el heroísmo de la épica clásica, que se había diluido en el sentimentalismo pasivo de la pareja, devolviéndole así al género parte de su grandeza prístina. No en balde enlazaba el género con Homero, o sea, se remontaba hasta el origen, cifrado en los aires novelescos que adoptaba la Odisea, cuya derivación hacia la narración de viajes y aventuras, antes del surgimiento de la novela helenística, sería proseguida por el alejandrino Apolonio de Rodas en El viaje de los Argonautas (siglo III a. C.) y, más tarde, por Virgilio en los seis primeros libros de la Eneida (17 a. C.). A la par que vinculaba, por medio del heroísmo, a la bizantina con la caballeresca, a la que venía a suplantar como fórmula predominante. La hipótesis parece tornarse en evidencia en el excelente libro II del Persiles, cuando el héroe narra a un amplio auditorio sus peripecias marinas como capitán corsario, como nuevo caballero andante de los mares, en el palacio del rey Policarpo; en cuya isla ya había hecho muestra, en una detención previa, de sus extraordinarias dotes atléticas al imponerse claramente en cuantas pruebas conformaban sus fiestas lúdico-deportivas. Cervantes alude explícitamente a la Eneida de Virgilio al hacer decir de Sinforosa que es, 
por la huida de su amado, "otra engañada y nueva Dido que de otro fugitivo Eneas se quejaba" (Persiles, II, XVII, p. 394). Pero igualmente subyace la estancia de Ulises en el reino de Feacia en todo el entramado narrativo que se monta en derredor de la isla y la corte. Resulta, además, que la extensa relación de Periandro, que morfológicamente está justificada como analepsis completiva del inicio in medias res de la trama y sancionada por el relato de Calasiris en la Historia etiópica de Heliodoro (libros II-V), tiene más que ver con la de Ulises en la corte de Alcínoo (cantos IX-XII) que con la de Eneas en la cartaginés de Dido (libros II-III), pues carece del hondo patetismo trágico de la narración del pater teucro, para derivar hacia los diversos tonos y múltiples escenarios del cuento de viajes y aventuras del de Ítaca (cfr. Muñoz Sánchez, 2008: 208-213).

La narración de Periandro forma parte de la larga secuencia de relatos fantásticos de fabulosos viajes a lugares semilengendarios o desconocidos, que pueden incluir el mundo supralunar y de ultratumba, y que son contados en primera persona por sus protagonistas, por la sencilla razón del "estuve allí, vi, oí y anoté". Puesto que el viajero que viajó a tierras exóticas y vivió lances increíbles es el único capacitado para rememorarlos con la precisión, el rigor y el detalle necesarios, para que la apariencia cobre visos de verdad. Su pretendida historicidad así lo prescribe: quien protagoniza las aventuras es el mismo que las rememora, quien las hace discurso. Conque se produce una perfecta adecuación entre aventura, palabra y protagonista, que impide dudar de la veracidad de la narración. Le correspondió en suerte a Luciano, en sus Relatos verídicos (siglo II) - -y, desde el diálogo, en el Icaromenipo-, ser el primero en poner en tela de juicio su supuesta verdad, así como decir que Homero había sido el precursor ${ }^{6}$. Con todo, la narración primopersonal siguió siendo la forma en que certificar las extraordinarias peripecias y las visitas al más allá; tal las aventuras de Sindbad el marino (noches 537-566), en Las mil y una noches (siglo IX), cuyos cuentistas expresan la misma fascinación que Luciano, su coterráneo, por las ficciones fantásticas; tal el viaje alegórico de Dante por el supramundo cristiano, en la Commedia (1304-1321). Sirvan de muestra estas palabras de Lázaro-atún a Vuestra Merced de que le quiere "dar cuenta de lo que nadie sino yo la puede dar, por ser yo solo el que lo vio, y el que de todos los otros juntos que allí estuvieron ninguno mejor que yo lo vi" (Segunda parte del Lazarillo, pp. 133-134), esto es, de sus andanzas subacuáticas. Cervantes,

\footnotetext{
6 "Su guía y maestro de semejante charlatanería es el Ulises de Homero — dice, que disertó ante la corte de Alcínoo acerca de vientos en esclavitud y de hombres de un ojo, caníbales y salvajes; y, además, de animales de múltiples cabezas y las transformaciones de sus compañeros a causa de los elixires: con múltiples relatos de ese género dejó maravilladas a gentes tan simples como los feacios" (Luciano, 1981: 180).
} 
por el contrario, heredero de Luciano en este y en otros aspectos ${ }^{7}$, discutirá metaficcionalmente la autoridad del narrador intradiegético. Así, carente del soporte objetivo y omnisciente del narrador extradiegético, dejará solo a Periandro para habérselas con un auditorio que ya no será tan crédulo como los "simples feacios" con Ulises. De suerte que el narrador-personaje no sólo tendrá que ganarse la confianza de sus receptores internos o narratarios a través de sus dotes verbales, su capacidad de fabulación y su poder de persuasión, sino que podrá verse desautorizado por quien le escucha (o le lee). Estos dardos envenenados que Cervantes consigna de diferente forma en el auditorio múltiple que recibe el cuento de Periandro apuntan nítidamente a la primera persona narrativa, a la que pone en crisis, y trasvasan la veracidad del autor al receptor, que es, en consecuencia, quien tiene la última palabra sobre lo narrado: "Tú, lector, pues eres prudente, juzga lo que te pareciere", había expresado, en Don Quijote (II, XXIV, p. 738), el cronista moro Cide Hamete Benengeli sobre el descenso del héroe a la cueva de Montesinos $^{8}$. Si en la Historia setentrional se enjuicia el relato autobiográfico del viajero, en El casamiento engañoso y El coloquio de los perros —en los que ocurre tres cuartas partes de lo mismo: "yo alcanzo el artificio del coloquio y la invención, y basta", le dice el licenciado Peralta, su receptor interno, al alférez Campuzano, autor de El coloquio - se alude, sin embargo, a la novela picaresca. La cual, como se sabe, se articula sobre la autobiografía del pícaro, de la que emana su historicidad y la univocidad del punto de vista sobre la realidad. Cervantes es siempre uno y el mismo. Lo que sucede es que entre la supuesta verdad histórica de las fantasías del viajero y las correrías del pícaro media un factor determinante: el "realismo" o la ilusión de realidad. Es decir, mientras que las primeras se amparan en lo desconocido, las segundas parecen, por su cotidianidad, por su contemporaneidad espacio-temporal y por la correferencialidad entre autor y narrador, tan reales como la vida misma. Cervantes se opuso frontal y radicalmente a ambas

${ }^{7}$ El magisterio de Luciano es discernible en aspectos cruciales para Cervantes como la defensa de la ficcionalidad (psê̂dos) de la literatura, la burla, la parodia, el humor, la ironía y el dialogismo, aunque se desmarque diáfanamente de la veta satírica del escritor sirio. Cabe pensar, pues, que en el relato de Periandro oficien de intertexto los Relatos verídicos, dado que coinciden en varios puntos: así, la descripción del ejército de esquiadores por parte del héroe cervantino parece una reminiscencia de los "corchópodos" o los hombres de pies de corcho de que habla el yo narrativo de Luciano que se deslizan por el mar cual surfistas; en ambos cuentos se repite el tema del barco encallado en un mar de hielo, y la isla paradisíaca que sueña Periandro no es muy diferente de la isla de los bienaventurados de Luciano, a pesar de que las dos forman parte del acervo común de las comarcas utópicas.

${ }^{8} \mathrm{Y}$ efectivamente, el descenso de don Quijote a la cueva de Montesinos y la resistencia de Sancho a creerle su cuento, frente a la confianza sin mácula del Primo, son, desde esta perspectiva, otra crítica más a la narración primopersonal, que ya ni siquiera halla fe en la palabra del caballero andante. 
y embistió contra ellas con su más fina ironía, sobre todo contra el nuevo género que nacía con el Lazarillo, pues era el que hacía de la pseudoautobiografía su marca genérica. Después de la crítica cervantina, los relatos extraordinarios insistirán en la primera persona, como sucede en Gulliver's Travels (1726) de Jonathan Swift o en la extraña The Narrative of Arthur Gordon Pym of Nantucket (1836) de Edgar Allan Poe. Pero no se echará en saco roto su metacrítica, y así, por ejemplo, Henry James se servirá de unos recursos narrativos parejos a los que emplea Cervantes, como el uso sabio de la perspectiva, los filtros, la ambigüedad y la infidencia, en The Turn of the Screw (1898), sobre todo en el preámbulo que enmarca y que precede a la lectura del relato y en ese caminar de la institutriz por el filo de la realidad y la fantasía, de la impresión demencial y la visión fantasmagórica.

Es palmario, pues, que en Los trabajos de Persiles y Sigismunda Cervantes sondea implícitamente sus avatares genéricos desde la antigüedad clásica hasta sus días, los remoza y les da un nuevo impulso en aras de la modernidad. Cierto: la Historia setentrional —al igual que La Galatea — arrumba de la poesía a la historia, transita por el orbe del mito para arribar al cronotopo de la vida cotidiana. Tanto es así que al llegar a la anhelada meta de la novela, la ciudad de Roma, los peregrinos, Periandro, Auristela y compañía, se topan de bruces con un mundo ajeno a su condición novelesca: el de La Celestina $(1499,1502)$ y La Lozana andaluza (c. 1530).

\section{LA NOVELA PICARESCA Y LA NOVELA DE CERVANTES}

Las obras de Fernando de Rojas y de Francisco Delicado, que por su forma dialogada son antecedentes directos de El coloquio de los perros, habían devenido fundamentales en el desarrollo de la ficción en prosa áurea. Habían abierto las puertas a la realidad circundante y familiar como ámbito de la ficción, habían hecho trizas las normas del decoro al dar relevancia poética a seres de baja o nula condición social y habían infundido vida a personajes que, por primera vez en la literatura europea, eran dueños de sí y responsables de sus obras.

Pero la auténtica revolución no aconteció sino en los primeros años del medio siglo del Quinientos con la publicación de La vida de Lazarillo de Tormes, $y$ de sus fortunas y adversidades, en tanto que un pregonero de vinos vecino de Toledo contaba su desastrada vida, desde su vil nacimiento hasta "el día de hoy", en que está en "prosperidad y en la cumbre de toda buena fortuna" como marido cartujo, a un Vuestra Merced que había pedido "se le escriba y relate el caso muy por extenso" (Lazarillo, pp. 79, 80, 5). Nacía así la autobiografía literaria, en la que el hombre, Lázaro, se explica a sí mismo por medio del mun- 
do y desde un punto de vista determinado: el famoso caso $^{9}$, al que se van sumando todas las etapas de su existencia como mozo de muchos amos. Y lo hacía bajo la forma de una carta, que era el tradicional vehículo para contar las confesiones y las confidencias; una "epístola hablada" probablemente más próxima al género retórico demostrativo o epidíctico que al judicial, que no vendría a ser sino una especie de encomio paradójico de acento burlesco o una adoxografía de los cuernos (cfr. Núñez Rivera, 2002).

El cuento de una vida, organizado desde una perspectiva tan única cuanto unipersonal y en una dirección señalada, pues, se presentaba en el mundo de unas letras dominadas por la narración de las hazañas heroicas y ejemplares, y suponía el primer conato de novela moderna, desde el realismo cómico y el relato corto. El Lazarillo, en función de su morfología epistolar, su talante petitorio-confesional o de relato de circunstancias es un diálogo a medias o parte de un proceso de comunicación, habida cuenta de que el tan innominado como enigmático Vuestra Merced "escribe se le escriba". Es por ello que Fernando Cabo Aseguinolaza (1992: 45-142) ha definido la autobiografía picaresca desde la perspectiva de su integración en una situación discursiva como "acto narrativo picaresco"10. Lo importante es que esta vida contada y armónicamente construida instituía el multiperspectivismo, impregnado de ironía y parodia, como clave esencial de su ética y de su estética, de su forma y de su fondo, que llevaba implícitas la ambigüedad y la polisemia semántica. Lo cual no quiere decir que haya un relativismo moral o un escepticismo absoluto por parte del anónimo autor, cuya intención parece diáfana y contraria a la de su personaje-escritor, si no es de "tejas para abajo", donde establece un enfrentamiento de perspectivas entre el destinador de la carta, su destinatario y el mundo, que ha de resolver el lector externo ${ }^{11}$. Con todo, la máxima aportación del La-

9 Sobre el caso, vid. Rico (1989: 21-25), García de la Concha (1981: 15-91), Ruffinatto (2001: 62-86), Rey Hazas (2003: 39-69).

10 "La configuración de la autobiografía de Lázaro, como inmersa en una situación independiente y anterior a ella — sostiene Cabo Aseguinolaza (1992)—, es la que define en general la autobiografía picaresca", de suerte que "lo característico de la serie picaresca no es tanto que el pícaro asuma la narración de su propia vida como la situación en que ésta narración se inscribe. Una situación de raíz dialogística, donde uno de los interlocutores, muchas veces implícito, se define por la superioridad social suficiente como para inducir al otro a que cuente su vida" (p. 63).

11 Aldo Ruffinatto, en uso del concepto bajtiniano de la "palabra ajena", advierte hasta tres voces diferentes en el discurso primopersonal de Lázaro: uno, la "palabra ajena", es decir, la palabra de los demás — del mundo_ - que se cuela, entretejida, en el relato del personaje-narrador; dos, la voz de Lázaro ironizando y parodiando la "palabra ajena"; y tres, la voz del autor anónimo, ocultada y disimulada en el discurso del pícaro narrador, que ironiza y parodia al yo narrado. La fórmula resultante sería: "palabra ajena vs palabra del narrador vs palabra del autor". Es así como existen dos niveles de parodias en el Lazarillo: "por un lado, el nivel de la palabra del narrador (parodia del primer grado), y, por otro, el nivel de la palabra del autor (parodia de segundo grado)". Conclusión: "la parodia dialéctica que [...] ha engendrado el Quijote y, con él, lo 
zarillo, aparte de su talante paródico-burlesco, estriba en la noción del tiempo como vivencia subjetiva e íntima del personaje novelesco ${ }^{12}$.

A pesar del éxito inmediato del Lazarillo - que, como se sabe tuvo una inmediata continuación en 1555, con la Segunda parte anónima, que diversificaba el relato hacia la sátira lucianesca y el tratamiento irónico del "romance"-, nadie se atrevió a emular su ejemplo hasta que Mateo Alemán, que esperó al fallecimiento de Felipe II, publicó en 1599 la Primera parte de Guzmán de Alfarache ${ }^{13}$, ocasionando un enorme revuelo en el incipiente mercado del libro y dominando abrumadoramente el panorama de la ficción en prosa del momento ${ }^{14}$.

que suele llamarse "novela moderna", esta misma parodia encuentra en el Lazarillo un primer espacio operativo, sea por lo que refiere al proceso de generación del texto, sea por lo que atañe a los elementos básicos para el nacimiento y desarrollo de la novela picaresca" (2000: 259-263 y 316-339, y 2001: 45-62).

12 Thomas Mann ponía en boca de Goethe esta reflexión que ilustra la genial contribución del anónimo: "Y esto es una permanencia vacía, sobrevivir en el tiempo exterior, sin el interno, sin biografía [...].Vacuo y aburrido hasta la muerte, querido mío, es todo ser que se mantiene en el tiempo en lugar de llevar el tiempo en sí mismo y crear su propio tiempo [...], de modo que fueran una y la misma cosa el devenir y el ser, el obrar y la obra, el pasado y el presente" (Mann, 2006: 405).

${ }^{13}$ Conviene recordar que antes que la Primera parte del Guzmán, el Lazarillo fue mencionado y, en parte, emulado por El Diálogo intitulado el Capón de Narváez de Velilla, sobre todo en la autodiégesis de Velasquillo, que, entre otros, tiene por amo a "un cura capón, que sin duda debió de ser pupilo del clérigo de Maqueda a quien sirvió Lazarillo de Tormes" (1993: 84; y antes hay referencias explícitas en las pp. 73 y 83). Vid. Asensio (2005: 133-148, esp. pp. 140-148). Pero es que, en el cambio de siglo, y tras la edición expurgada del Lazarillo (1573), lo picaresco se respiraba en el ambiente. Así lo certifican piezas teatrales de Lope como El caballero del milagro, El rufián Castrucho, El anzuelo de Fenisa y El caballero de Illescas, todas fechadas entre 1593 y 1606, que Joan Oleza (1991) no ha dudado en denominar "comedias de pícaros".

14 A pesar de que abordo el Guzmán en conjunto, conviene subrayar que no fue publicado unitariamente, sino en dos partes separadas por un hiato temporal de cinco años. Ello comporta que la Primera parte se presente no como un libro cerrado sino abierto, en el que, más allá del deseo de contar su vida (I, I, 1), tal vez para acallar las voces de los murmuradores y por su afán reformista, ignoramos por qué escribe Guzmán. En efecto, Mateo Alemán dice, en la "Declaración para el entendimiento deste libro", que Guzmán "escribe su vida desde las galeras, donde queda forzado al remo por delitos que cometió, habiendo sido ladrón famosísimo, como largamente lo verás en la segunda parte. Y no es impropiedad ni fuera de propósito si en esta primera escribiere doctrina; que antes parece muy llegado a razón darla un hombre de claro entendimiento, ayudado de letras y castigado del tiempo, aprovechándose del ocio de la galera" (1987: I, 113). Pero, como se ve, no menciona la conversión como piedra angular por la cual Guzmán toma la pluma y escribe la historia de su vida. Sólo al comienzo de la segunda parte menciona el yo narrador el arrepentimiento y denomina a su discurso confesión general: "Hice cuenta con el almohada, pareciéndome, como es verdad, que siempre la prudente consideración engendra dichosos acaecimientos; y de acelerarse las cosas nacieron sucesos infelices y varios, de que vino a resultar el triste arrepentimiento... Digo -si quieres oírlo- que aquesta confesión general..." (1987: II, II, I, I, 40 y 42). Al tiempo que el autor comenta que la pretensión de su historia no fue sino "descubrir - como atalaya- toda suerte de vicios y hacer atriaca de venenos varios un hombre perfecto, castigado de trabajos y miserias, después de haber bajado a la más ínfima de todas, puesto en galera por curullero della" (1987: II, 22). Por otro lado, fue la Primera parte la 
La novela de Mateo Alemán, de una admirable perfección morfológica, no se constituía sin más en una servil continuación genética y genérica del Lazarillo, sino que lo readaptaba profundamente conforme a sus intereses creadores e ideológicos. Mantenía la autobiografía articulada desde un punto de vista como eje del relato, pero ocultando la situación narrativa. Reducía, sin eliminar, la ambigüedad, la ironía y la pluralidad de significados en aras de una visión monocorde de la realidad emanada de la compleja interioridad del pícaro: la atalaya desde la cual el yo narrador, escarmentado, en búsqueda de la perfección ética y en disconformidad ideológica con su vida pasada, adoctrina al lector sobre la condición humana y la necesidad de una reforma sociomoral del hombre. Mateo Alemán quebrantaba el pacto autobiográfico del anónimo quinientista y de su continuador de Amberes, basado textualmente en la identidad de autor, narrador y personaje, al disociar nítidamente al autor empírico del yo narrador, acentuando con ello el talante marcadamente ficcional de la autobiografía; cuya práctica se haría norma en la serie picaresca, fuera del Estebanillo González (1646). Asimismo, modificaba notablemente al receptor ficticio de la autobiografía de Lázaro, el Vuestra Merced, para que su pícaro dialogara directamente, más bien monologase en atención a, tanto con un narratario polivalente y plurivocal no identificado, como consigo mismo en sostenida reflexión e introspección, desdoblándose en locutor y alocutorio.

El escritor sevillano, preocupado por el mensaje y su eficacia, ponía sobre el tapete la autodiégesis espiritual del hombre, ser imperfecto y perverso, en contacto con una sociedad vil, desde el pecado original en que fue concebido hasta su supuesta contrición y conversión moral, desde las que echa la vista atrás. Palabras y actos, consejas y consejos, conforman así el entramado, la contextura de la autobiografía, de tal suerte "que la vida narrada, naturalmente a posteriori, esté concebida a priori como ejemplo de desengaño" (Blanco Aguinaga, 1957: 326). Mientras tanto, así se llega a la iluminación, Guzmán, en uso del libre albedrío, se balancea entre la maldad y la virtud, para siempre caer y retornar al vicio y a la mala conciencia que lo acompaña. Una suerte de desgarro íntimo que informa el texto en unión inextricable de lo humano, lo estilístico y lo ideológico que va "de la definición a lo definido". No en vano, Mateo Alemán redactó, para el pórtico de su Guzmán, una intencionada aser-

que obtuvo un extraordinario éxito de ventas, alcanzando, entre legales y piratas, hasta veintidós ediciones entre 1599 y 1604; la Atalaya de la vida humana alcanzó solamente cinco entre 1604 y 1605, para desaparecer del mercado hasta 1615 (primera edición conjunta) tal vez por la irrupción de El ingenioso hidalgo don Quijote de la Mancha. Con ello quiero significar que no fue el Guzmán en conjunto ni la Atalaya sino la Primera parte la referencia textual con que trabajaron y frente a la que reaccionaron Luján de Sayavedra, Gregorio González y López de Úbeda. Lo mismo Cervantes para la elaboración del Quijote de 1605 y la primera versión de Rinconete y Cortadillo; pero no para la de El casamiento y El coloquio. 
ción titulada "Declaración para el entendimiento deste libro", a seguida de dos prólogos, uno al vulgo ignorante y otro al discreto lector, como fórmula en la que encapsular el significado y el sentido de su novela. Pues su propósito, ético a la vez que estético, no consistió sino en imbricar el provecho y el deleite, el humor de la autobiografía de Lázaro y la dignidad moral de la autodiégesis de san Agustín. No obstante su fin doctrinal, conviene señalar que se termina por imponer en el Guzmán una "contienda" de pareceres ("o te digo verdades o mentiras"), tanto, que uno puede dudar de la sinceridad de la palabra del pícaro ${ }^{15}$ y más aún de que esté en disposición de la verdad en razón a la superioridad moral que deriva de la conversión ("que quien una vez ha sido malo — sentenciaba Guzmán sobre la conversión de su padre—, siempre se presume sello en aquel género de maldad").

Mateo Alemán, además, convertía al protagonista del anónimo en un pícaro con todas las de la ley, hacía de Guzmán un disidente y un delincuente ocasional que bordea la marginalidad en el seno de la sociedad. Al mismo tiempo que le hacía relacionarse con un estrato humano y un cuerpo social más amplio que el de Lázaro, que engloba a todos los estamentos, incluidos el alto clero y la nobleza, cuya ideología e idiosincrasia representan el cardenal y el embajador francés; y que está en sintonía con sus mayores aspiraciones ("quise hacerme de los godos"). E, igual de importante, extendía y ampliaba el Lazarillo en su aspecto y en su contenido hasta imprimirle la forma de una narración de largo recorrido. En efecto, "todo es exuberancia, derroche y proliferación en el Guzmán de Alfarache y su alrededor" (Guillén, 2002: 65): así, a las consejas y los consejos se les une todo tipo de digresiones, novelas sueltas y cuentos, anécdotas y chascarrillos, dichos y sentencias... y mil zarandajas más, porque, como advierte el mismo autor, "en las mesas espléndidas manjares ha de haber de todos los gustos, vinos blandos y suaves, que alegrando ayuden a la digestión, y músicas que entretengan” (Guzmán de Alfarache, I, p. 94).

Había nacido, por consiguiente, la gran novela barroca, y, en comunión con el Lazarillo, la prescripción del género "novela picaresca". A seguida del Guzmán, y a su rebufo, se escribieron en los años siguientes, ya como emulación, ya como respuesta, tres novelas picarescas, que constituyen su fase de institucionalización: La segunda parte de la vida del pícaro Guzmán de Alfarache (1602) de Juan Martí, El guitón Onofre (1604) de Gregorio González y La pícara Justina (1605) de López de Úbeda; a las que hay que sumar nueve ediciones del Lazarillo castigado.

En esta apoteosis de lo picaresco un escritor, castigado por el tiempo pero sin cuentas que ajustar, tiene la feliz idea de hacerse personaje de ficción del libro que está escribiendo para adquirirlo por acaso en un mercado toledano. Dice J. C. Rodríguez (2003: 151-152) que 
El escritor que compró su propio libro nos está configurando verdaderamente la nueva imagen del escritor (...). Pues está claro que al comprar su propio libro, lo que Cervantes nos está vendiendo es la expresión de su propia alma (o mens o "inteligencia") viva y únicamente suya. Ya no depende (su "alma" o su mens) de ninguna relación con ningún señor o con ningún vasallaje feudal: es libre. De ahí la importancia de categorías como las de invención u originalidad.

Azar, libertad, invención, originalidad no constituyen sino lo que Cervantes presenta como mercadería al mundo con El ingenioso hidalgo don Quijote de la Mancha. Un texto que carece de antecedentes previos, por más que se inserte en la cadena que va de La Celestina al Guzmán, y que no tuvo sucesores hasta el siglo XVIII inglés; pero que, en cambio, hubo de luchar a brazo partido con la novela picaresca para ser. Y bien que lo consiguió, puesto que su impresión en 1605 trajo consigo el ocaso editorial del género, incluida la novela de Alemán. Hasta que, a continuación de la publicación de La hija de Celestina (1612) de Salas Barbadillo, volviera a irrumpir con renovado ímpetu alrededor de los años veinte del siglo XVII, con obras tales como el Marcos de Obregón (1618) de Vicente Espinel, La desordenada codicia de los bienes ajenos (1619) de Carlos García, la Segunda parte del Lazarillo (1620) de Juan de Luna, Lazarillo de Manzanares (1620) de Cortés de Tolosa, Alonso, mozo de muchos amos (1624-1626) de Alcalá Yáñez y La vida del Buscón (1626, ms. circa 1620) de Francisco de Quevedo.

Joaquín Casalduero, precursor de no pocos aspectos del cervantismo crítico, dejó escrito que "quizá nadie leyó al Guzmán con más atención que Cervantes, el cual "se separó" por completo del mundo picaresco, que juzgaba tan unilateral como el renacentista" (apud. Castro, 2002b: 82-83, n. 47). Mucho se ha escrito desde entonces en torno a la relación de Cervantes con Mateo Alemán y con la picaresca en general. Claudio Guillén (1988), sin ir más lejos, en su importante artículo sobre el descubrimiento del género picaresco, constataba que Cervantes, al poner en boca de Ginés de Pasamonte aquello de "mal año para Lazarillo de Tormes y para todos cuantos de aquel género se han escrito o escribiesen", era, si no el primero en fusionar la anónima novelita con el Guzmán, sí en formular el concepto de género picaresco; cuya respuesta más contundente, en especial a la novela de Alemán, más que en el Quijote, se cifraba en El coloquio de los perros ${ }^{16}$. Unos años antes, en 1957, Carlos Blanco

${ }^{15}$ Claudio Guillén (1985: 182), con su habitual perspicacia crítica, argüía que "la autobiografía del pícaro no es como cualquier otra, puesto que evoca las antiguas aporías de Crisipo el Estoico (Epiménedes el Cretense afirma que todos los cretenses mienten, etc.): la novela picaresca es la confesión de un embustero".

${ }^{16}$ Empero, Guillén (1985: 147), al socaire de su aproximación a la genología desde una perspectiva estructural' ("el género se ha considerado no como un elemento aislado sino como parte 
Aguinaga (1957) publicaba su estudio sobre la diferencia radical que separa el "realismo" cervantino del picaresco. En él confrontaba al Guzmán precisamente con El coloquio de los perros, y también con Rinconete y Cortadillo y La ilustre fregona, mas no con Don Quijote. Sin embargo, su conclusión era extensible a él tanto como al resto de la producción cervantina, por cuanto, frente a la visión monocorde, desengañada, trascendental, cerrada, pesimista y dogmática de Alemán, el complutense conformaba un mundo sin horizontes, abierto y flexible, repleto de vida, en el que los personajes no son sometidos a proceso, sino que se están haciendo a su albedrío y según dictan las circunstancias. El artículo de Blanco Aguinaga se convirtió rápidamente en un pozo sin fondo para el cervantismo, así como para los estudiosos de la picaresca, especialmente para el propio Guillén, Lázaro Carreter y Francisco Rico. Américo Castro, que en El pensamiento de Cervantes (1925) ya había analizado la relación dialógica de la novela picaresca, de la que separaba el Lazarillo aun siendo su precursor, de la novela cervantina, hizo suya tal tesis, y, en Cervantes y los casticismos españoles (1966), encaraba a Cervantes con Alemán, pero esta vez con el Quijote en mano ("el Guzmán y el Quijote han de ser concordados con ellos mismos antes que con nada exterior a ellos"), porque, según decía, "Cervantes ha introducido una nueva dimensión en la literatura [con Don Quijote], la de trazarse la figura imaginada su propia vía, enfrentándose en tácita polémica con el Guzmán de Alfarache (1599), de Mateo Alemán" (Castro, 2002b: 75 y 79. Vid. también 2002a: 213-221 y 423-458). Fernando Lázaro Carreter, en su fundamental ensayo de finales de los años sesenta "Para una revisión del concepto 'novela picaresca", no sólo sostenía que "la oposición más neta al Guzmán y, con ella, al género que nacía, fue [...] la de Cervantes", en tanto en cuanto "advirtió con perspicuidad genial las cuatro amenazas que el Guzmán implicaba contra el arte de narrar: el relato inorgánico, la monotonía del héroe, la moralización, y la imposición al lector de una sentencia definitiva sobre el mundo"; igual de importante fue su dictamen de que "trató de pícaros, pero no escribió picaresca porque se opuso a su poética punto por punto" (Lázaro Carreter, 1978: 195-229, esp. pp. 226-228). No es mucho, pues, que unos años después, Marcel Bataillon (1973: 232) sostuviera la idea seminal de que "mejor tal vez que las reticencias ante la creación lopesca y la crítica del mundo fabuloso de las caballerías, la actitud explícita de Cervantes ante la picaresca determina el eje de su relación con la literatura de su tiempo y la conciencia que tuvo de su propio valor". Fue obra de Gonzalo Sobejano (1976-1977) no el enfrentar a los

de un conjunto. Es decir, de un conjunto de opciones, de alternativas, de interrelaciones") y de su noción de "contragénero", expuesta por primera vez en Literature as System (1971), matizaba que "hay géneros que son contragéneros; u obras cuyo origen es contragenérico. La protonovela de Cervantes es en parte una respuesta a la narración picaresca, que el Quijote y varias "novelas ejemplares" procuran dejar atrás". 
dos novelistas, sino el ponerlos a dialogar en su revelador ensayo "De Alemán a Cervantes: monólogo y diálogo". Poco después Edward C. Riley (1981: 11), en un importante trabajo sobre la cuestión del género en Cervantes, dijo, con su cautela habitual, que "es probable que, en cierto sentido, y hasta cierto punto, el Quijote era respuesta a Alemán"; una idea mantenida en trabajos suyos posteriores, si bien matizada y sin caer nunca en excesos. Francisco Márquez Villanueva, en "La interacción Alemán-Cervantes", defendía una relación de ida y vuelta entre el escritor del Guzmán y el de Don Quijote, y, aunque centraba su comparación en la vinculación contestataria de El coloquio de los perros con el Pícaro, lo cierto es que venía a decir que "toda su obra novelística posterior a La Galatea se halla marcada más o menos de cerca por la meditación de aquella ruptura [la que suponía el nacimiento del "yo" picaresco] y de su propio papel o espacio de maniobra en la periferia de la misma" (1995: 151). Como colofón del estudio de las relaciones vitales y escriturales del sevillano y el complutense, así como suma de sus análisis de la novela picaresca y de Cervantes, ha de entenderse el trabajo de Antonio Rey Hazas, "El Guzmán de Alfarache y las innovaciones de Cervantes" (2002), en cuanto recoge y critica lo anteriormente dicho sobre el tema, a la par que enfrenta la novela de Alemán, sucesivamente, a Rinconete y Cortadillo, Don Quijote y El coloquio de los perros; para concluir con la idea de la oposición y con la de que la obra de Cervantes, en adelante de la publicación del Guzmán, se ve tácita e indudablemente influenciada por él.

Es necesario destacar que en este sucinto repaso bibliográfico sobre Alemán y Cervantes nos hemos dejado en el tintero ensayos tan importantes como los de Alban K. Forcione (1984), Joseph V. Ricapito (1985), Agustín Redondo (2005), Edwin Williamson (1991), Stanislav Zimic (1996), Monique Joly (1999), Jorge García López (1999), Edmond Cros (2002 y 2005), Mercedes Blanco (2007) y Katharina Niemeyer y Klaus Meyer-Minnemann (2008), entre otros, que tratan o bordean el asunto en cuestión desde distintas perspectivas y alcances; pero con la convicción de que los textos de Alemán y Cervantes entablan un diálogo contradictorio, conflictivo y constructivo del que nace la novela moderna.

Por otro lado, hay que tener en cuenta por su repercusión el artículo de Gonzalo Sobejano de 1975, "El Coloquio de los perros en la picaresca y otros apuntes", y ello porque no sólo aduce motivos por los que incluir la última de las Ejemplares en el canon picaresco, a tenor del criterio expuesto para la comprensión del género por Lázaro Carreter, sino también por la revisión que efectúa del caso del Lazarillo, puesto que anticipa otras lecturas posteriores, como las de Víctor García de la Concha y Antonio Rey Hazas, que inciden más en el cursus honorum que el ménage à trois como motivo por el cual Lázaro expone por extenso su vida a Vuestra Merced. Como también el de J. B. Avalle-Arce, "Cervantes entre pícaros", así porque repasa las aproximaciones cervantinas a 
la picaresca en duelo con Alemán, como sobre todo porque arguye con perspicacia que quizá "Cervantes no vio la picaresca como un género acabado, sino como algo decididamente haciéndose. La poética del Guzmán no era para él una preceptiva, sino una opción: nada estaba finiquitado, todo estaba in fieri (...); la consagración de la forma guzmaniana fue una labor cumulativa, y en ella no participó Cervantes. Él llevó adelante sus propias aproximaciones y acosos a un género todavía abierto a sugestiones" (1990: 600). Lo que de algún modo viene a coincidir con la concepción de la novela picaresca como la construcción de un género en proceso de desarrollo sobre la base de unos rasgos diferenciales, desde su prescripción, establecida por la imbricación formal del Lazarillo y el Guzmán, hasta su agostamiento con el Estebanillo González (1646).

Es mi opinión que Cervantes no escribió nunca una novela picaresca. Por lo menos no de forma estereotipada, según los parámetros formales y temáticos fijados por el Lazarillo y el Guzmán. Pero sí meditó y reparó con hondura en los postulados que la informan. Ninguno de sus textos narrativos se construye sobre la autobiografía ficcional de un pícaro, sino siempre sobre la de un narrador heterodiegético-extradiegético, aunque sea solamente para presentar a un narrador homodiegético-intradiegético, como sucede en El casamiento engañoso ${ }^{17}$. Para Cervantes la primera persona, a causa de su visión sesgada y unívoca, puede falsear y silenciar la realidad, por lo que intrínsecamente es indigna de confianza, máxime si se trata de la de un pícaro. Cuando no equivocarla fatalmente, cual le ocurre, por ejemplo, a Cardenio, que hubiera muerto desesperado si por obra del azar (o de don Quijote) no se hubiera topado con Dorotea en Sierra Morena, quien le informa sin querer de lo que realmente acaeció en la boda de don Fernando con Luscinda. Además, como critica Ginés de Pasamonte, la autobiografía resulta imposible por incompleta, aun cuando se articule sobre un principio escogido, pues ha de basarse en un criterio de selección, y no puede desentrañar el meollo de una vida que sólo cobra sentido desde el vértice de la muerte, lo cual refuerza su inverosimilitud. Añádase que las narraciones cervantinas fluyen, no en corriente alterna del pasado al presente y del presente al pasado, sino del presente al futuro, lo cual comporta la apertura a lo desconocido que, en su incertidumbre, permite la mutación del carácter y el quiebro inesperado.

Tampoco ninguna de sus obras se edifica alrededor de la figura de un pícaro y su trayectoria vital. No se ajusta ciertamente a la convención picaresca en

17 Bien es verdad que hay textos de la serie picaresca que no se configuran sobre un relato autobiográfico, sino que este aparece enmarcado, como es el caso de La hija de Celestina (1612) de Salas Barbadillo y la Vida de don Gregorio Guadaña, insertada en El siglo pitagórico (1644) de Antonio Enríquez; o subsumido completamente en un relato autorial, como en las novelas de Castillo Solórzano, Las aventuras del bachiller Trapaza (1637) y La garduña de Sevilla (1642). Ensayos todos posteriores a Cervantes, salvo La hija de Celestina y su reescritura, La ingeniosa Elena (1614). 
el origen vil del héroe, pues ninguno de sus personajes apicarados la manifiesta claramente. Ni por la soledad, pues el "solo soy" que aprende a las primeras de cambio Lazarillo, y el "pensar cómo me sepa valer" no tienen paralelo en las novelas de Cervantes que, a excepción de El licenciado Vidriera, se cimientan en derredor de una pareja. Ni por el consabido afán de medro que caracteriza al pícaro tanto como al género, por cuanto "elegir la novela picaresca significa (...) tratar el tema de la posibilidad o imposibilidad de ascenso social en la España del Siglo de Oro" (Rey Hazas, 2003: 21). Ni por su insuficiencia sentimental, esa desconfianza para con el otro, que expresa repetidamente Guzmán, pues "a mí me parece que son todos los hombres como yo, flacos, fáciles, con pasiones naturales y aun estrañas", cuya razón es inoperante en el mundo cervantino, donde todos sus moradores, para bien o para mal, aman y hacen amigos, se arriesgan a romper las barreras sociales y linguísticas que los separan.

Cervantes, por otro lado, no escribió nunca una novela sustentada en el esquema Individuo problemático-Realidad degradada, sino más bien en el choque brutal entre Ilusión y Realidad; pese a que El coloquio de los perros dibuje un panorama social en el que campea el vicio, la maldad y la apariencia, que a la postre se subsume en la lección humanista de que "la virtud y el buen entendimiento siempre es una y siempre es uno, desnudo o vestido, solo o acompañado. Bien es verdad que puede padecer acerca de la estimación de las gentes, mas no en la realidad verdadera de lo que merece y vale (El coloquio de los perros, p. 623). A contrapelo de los personajes de la picaresca, los de Cervantes no toman la pluma para mudar su vida en discurso literario, sino la literatura en una extensión de la vida, en una vivencia, y cuando refieren sus experiencias pasadas se sirven de la oralidad, nunca de la escritura ${ }^{18}$. De hecho, el más excelso escritor de su obra, el alférez Campuzano, no escribe su historia matrimonial, que se la cuenta verbalmente a su amigo el licenciado Peralta, sino que lo que pone en caracteres es una obra de invención, El coloquio de los perros, en la que, de forma implícita, establece el itinerario histórico-genérico de la picaresca, desde la más rancia antigüedad hasta su presente; al mismo tiempo que desenmascara sus principios poéticos y los trasciende en una nueva forma de novelar: la narración calidoscópica. Mas el caso egregio es el de Alonso Quijano que, en vez de continuar el Belianís, como "muchas veces le vino el deseo de tomar la pluma, y dalle fin al pie de la letra", "vino a dar en el más

18 Hay pícaros, cierto, que no escriben su vida: la cuentan en una situación comunicativa, como sucede en Marcos de Obregón y en Alonso, mozo de muchos amos; y, desde otro ángulo, con la relación de Elena a Montúfar, en La hija de Celestina. Lo cual tal vez se deba a una influencia suya. En cualquier caso, recuérdese que Gonzalo Sobejano analizó la "locuacidad crítica" de los pícaros en "Un perfil de la novela picaresca: el pícaro hablador", (Sobejano, 1972-1975: 467-485). A tal propósito, son fundamentales las rectificaciones de F. Cabo Aseguinolaza (Cabo Aseguinolaza, 1992: 74-107). 
estraño pensamiento que jamás dio loco en el mundo, y fue que le pareció convenible y necesario, así para el aumento de su honra como para el servicio de la república, hacerse caballero andante" (Don Quijote, I, I, pp. 35 y 36), vale decir, hacer de su vida una obra de arte. Hay, por fin, un motivo más por el que Cervantes no se enfrascó en la aventura literaria de la picaresca: se trata de su visión satírica del mundo, o mejor de la intencionalidad satírico-crítica que la anima, en tanto es contraria a su pensamiento, pues, para él ni el murmurar es filosofar ni le vale el humor cáustico como expresión cínicamente desoladora de la depravación humana (cfr. Close, 1990 y 2007) ${ }^{19}$. Cervantes, como señaló Riley (2001c: 238): “como hombre, sabía muy bien lo que significaba sentirse cínico. Pero como escritor sabía como convertir hasta las experiencias dolorosas en arte y, con ello, trascenderlas".

Comparto, asimismo, la tesis de que Cervantes no dejara de pensar nunca en el Guzmán en los años inmediatamente posteriores a la publicación de sus dos partes, como lo atestiguan el Quijote de 1605, sobre todo por el encuentro del caballero con Ginés de Pasamonte, Rinconete y Cortadillo, La ilustre fregona, El casamiento engañoso y El coloquio de los perros. Pero me parece excesivo pensar que dominara toda su obra posterior a La Galatea o que ejerciera sobre él una suerte de amor/odio arrastrada hasta el final de sus días. Pues la segunda parte del Quijote no depende y emana, según viera Américo Castro, sino de la primera, y, en todo caso, si apunta a algún texto específico, ese es el Quijote espurio (1614) de Avellaneda. Ni siquiera cabe pensar que la erradicación en la segunda parte de las novelas sueltas y pegadizas sea una respuesta tácita al uso abrumador de la digresión narrativa en el Guzmán, pues la "variedad en la unidad" era la clave morfológica de la teoría y la práctica literarias de su tiempo. Más bien, como se declara explícita y metaficcionalmente en los capítulos III y XLIV del Quijote de 1615, se trata de una evolución personal de Cervantes, que estriba en su meditación sobre el arte de hacer novelas. Máxime cuando no elimina ni la digresión episódica, pero emanada de la acción central, ni la ideológica, que se refuerza espectacularmente con la plurivocidad autorial, tanto en la segunda parte del Quijote como en Los trabajos de Persiles y Sigismunda. Ambas obras no dejan de tener un elevado número de intrigas secundarias que completan y complementan la trama medular allí donde ella no puede llegar por mor de sus características, así como de comentarios metaficcionales que versan sobre factores que se concentran en la naturaleza literaria de la propia novela. En conjunto, las Ejemplares tampoco remiten al Guzmán, en cuanto que la intención de Cervantes es presentar a la república de las letras una colección de cuentos, doce laberintos, doce experimentos, que sean originales y "no imitadas ni hurtadas" ni "traducidas de lenguas extranjeras"; inclasifi-

${ }^{19}$ Sobre el humor como rasgo caracterizador de la picaresca, vid. Roncero López (2010). 
cables, además, genéricamente, pues, como ha visto Peter Dunn (1973: 93), “en las Novelas ejemplares no hay ni novelas picarescas ni verdaderas novelas de aventuras". Y, desde luego, la Historia setentrional pertenece a otra esfera de la imaginación o mundo posible radicalmente dispar del picaresco, el de la épica amorosa en prosa, que, no lo olvidemos, también domina el panorama literario del momento, tanto, que se convertirá en la vanguardia de la prosa de ficción española y europea, sobre todo francesa, a lo largo del siglo XVII; por lo que la impronta del Guzmán, más allá de ciertas reminiscencias, pasajes o episodios aislados, es inoperante o nula en el conjunto de su génesis y evolución.

Con todo, Cervantes hubo de aprender no poco del Guzmán, especialmente en lo relativo a la creación y conformación de un texto narrativo extenso concebido como una "ficción cómica" o un "poema cómico en prosa", contrario a la práctica del "romance", multiforme y pluritemático. Mas también, y no en menor medida, del Lazarillo, obra con la que del mismo modo compite, a pesar de que fuera ya un texto viejo para 1605, pero que sin embargo estaba de máxima actualidad, en función de la revalorización editorial de su edición castiga$d a$ al arrimo del éxito del Guzmán. Cervantes leyó con profundidad, deleite y provecho la anónima novelita. De ella tomó, para llevarlo a cotas insospechadas, el perspectivismo, la ironía, la parodia, la distancia autorial sobre el enunciado, la relación emisor-receptor internos, los "blancos" o los "silencios" semánticos, el tiempo vivido, la lengua y el estilo; por más que desechara la narración primopersonal como forma y como fórmula. Es, no en vano, el Lazarillo el libro que cita Ginés, no tanto, que también, por eludir el Guzmán, cuanto por remontarse hasta la primera manifestación genérica del módulo picaresco, y no es sino como novela corta con la forma ficcional con que Cervantes arremete contra la extensa novela de Alemán. No de otro modo, Rinconete y Cortadillo, además de por su talante festivo, al ser el cuento de dos ladronzuelos adolescentes que no van a más, está más próximo al modelo picaresco del Lazarillo que al del Guzmán, que tendría su paralelo en la cofradía de ladrones de Monipodio y en esa irónica confusión entre delincuencia y piedad. Ahora bien, no se puede pasar por alto que este era un tema que preocupaba a Cervantes desde antes de la irrupción del Pícaro, como lo corrobora El rufián dichoso. Le rinde un caluroso homenaje en La ilustre fregona, no sólo porque las correrías de Carriazo y Avendaño tengan lugar en la ciudad imperial, sino también porque Carriazo, "el pícaro virtuoso, limpio, bien criado y más que medianamente discreto" (La ilustre fregona, p. 374), desempeña, como Lázaro, el oficio de aguador. Y en la bilogía El casamiento engañoso-El coloquio de los perros, la más honda y meditada respuesta cervantina al Guzmán, se halla bien presente el Lazarillo, sobre todo a través del esquema emisor-receptor y el acto discursivo en que acaece, aunque Cervantes lo modifique notablemente al transformar el medio diálogo de la novela anónima en viva plática, así el 
narratario calle, como Peralta, o intervenga constantemente, como hace Cipión, y enjuicie la primera persona en general con la narración intradiegética de Campuzano y la picaresca en particular con la de Berganza.

\section{EL QUIJOTE Y LAS NOVELAS EJEMPLARES}

Sucede que el Quijote no es una antinovela picaresca, como tampoco es un antilibro de caballerías, sino la superación consciente de ambos géneros en una realidad literaria flamante que se llamará 'novela moderna', pero que empezó configurándose como libro de entretenimiento, esto es, como una ficción que se presenta como una ficción, con la que combatir el tedium vitae, y que aporta un conocimiento, pues su estética lleva implícita una ética, ya que para Cervantes, la verdad poética y la moralidad eran inseparables, cuya aprehensión le corresponderá al lector prudente y avisado extraer por cuenta propia. El profesor Riley, con su acostumbrada pericia crítica, demostró que la máxima novela cervantina abrazaba en su seno, entre otros varios géneros, a la picaresca y a la caballeresca, de forma paródica y burlesca, al equipararlas como una sola profesión que implica el viaje en busca de aventuras, en el episodio en que don Quijote es armado caballero por el ventero. Escribía el gran cervantista anglosajón que

la nota burlesca se intensifica si vamos allá en la observación de los dos personajes. Uno de ellos no es un caballero andante genuino, sino un aspirante a la caballería que no pasará de eso. El otro no es un pícaro en activo, sino retirado. Ninguno es un representante ideal del género literario con el que se asociaba, como si ambos se inclinaran hacia un terreno intermedio común. Don Quijote, que ha dejado su hogar de hidalgo provinciano en búsqueda de un estilo de vida más emocionante, se encuentra con el hombre que tiene a sus espaldas una vida de sórdidas aventuras y se ha instalado, literalmente, en un alto en el camino hacia la respetabilidad. Antes, cuando un caballero literario se encontraba con un rufián literario, como ocurría alguna que otra vez, solía ser en el territorio literario de uno u otro. En el Quijote, estas dos figuras antitéticas se encuentran en un terreno neutral entre dos mundos sociales y estilísticos separados. El encuentro se sitúa en un tercer espacio, uno nuevo, genéricamente diferente (aunque anticipado, en parte, por la Celestina). Debía ser un género narrativo nuevo, genéticamente diferente y lo bastante amplio para contener a los dos. Así, el encuentro es más que la reunión de dos personajes literarios: en realidad se trata de una confrontación de dos géneros prácticamente irreconciliables. Probablemente por primera vez en la historia literaria, un escritor completamente consciente de las implicaciones que hacía los reunía en un mismo nivel (2001b: 211-212).

Y lo mismo cabe decir del encuentro de don Quijote y Ginés de Pasamonte. Cervantes volvería a conjugar en mixtura imposible y paradójica la no- 
vela picaresca y los libros de caballerías, sólo que desde otra perspectiva, en $L a$ ilustre fregona, al hacer de Carriazo y Avendaño dos caballeros-pícaros. Es importante echar la vista atrás, porque el escritor anónimo que decidió continuar el Lazarillo adoptó, no sin jocosidad, no sólo hacer de Lázaro un pez, sino del pícaro un heroico caballero de los submundos marinos. Claro está que en su época, allá por los aledaños de 1555, casi todos los géneros, en menor o en mayor grado, como sucederá con el Guzmán cincuenta años después, eran una respuesta crítica, incluso contragenérica, a los libros de caballerías. Así, por ejemplo, Núñez de Reinoso arremete duramente, en la carta-prólogo a don Juan de Micas que encabeza su obra en verso, contra la caballeresca y su inverosimilitud; a la que pretende rectificar con el Clareo y Florisea, en la que, en mescolanza de géneros, incluye un relato de caballerías, pero modélico y ejemplar: el de don Felesindos (caps. XXII-XXXI). Y si miramos al futuro, nos toparemos, por caso, con que Clarín, crítico eximio, cervantista de pro y consumado maestro de la intertextualidad, volverá a jugar con el apareamiento de los dos géneros antitéticos en su novela corta Pipá (1886).

En la primera parte del Quijote Cervantes, por medio de Ginés de Pasamonte y a través del empleo de la alusión y la elusión, establecía como una especie genérica a la novela picaresca, cuya primera manifestación remontaba al Lazarillo, pero cuya consolidación no se había producido sino en conjunción con el Guzmán, así como con el resto de obras que, derivadas de ellos, "se han escrito o escribieren". Sin embargo, en sus páginas no se consigna el recorrido histórico-literario de la picaresca, sino, más bien, el de los libros de caballerías, desde el Amadís de Gaula, que "fue el primero de caballerías que se imprimió en España, y todos los demás han tomado principio y origen deste"; el de la novela caballeresca, con la mención de la Historia del famoso caballero Tirante el Blanco (1490; 1511 la trad. castellana) de Johanot Martorell y del continuador Martí Johan de Galba, en tanto "aquí comen los caballeros, y duermen y mueren en sus camas, y hacen testamento antes de su muerte, con estas cosas de que todos los demás libros desde género carecen" (Don Quijote, I, VI, pp. 71 y 77), y de la épica española, surgida a raíz de la épica culta italiana, con el Orlando furioso (1532, la versión definitiva) de Ludovico Ariosto a la cabeza, y de las traducciones de la Odisea (1550-1556) y la Eneida (1555). Géneros y obras que tan importantes serán para la intención de don Quijote de resucitar la caballería andante en ese su tiempo y para la estructura global del texto. Ello demuestra diáfanamente que con el Quijote, aunque esté latente en sus páginas, Cervantes se atreve a competir con Alemán no en el terreno de este, sino en el suyo propio: en su personal concepción de la novela.

Con El casamiento engañoso y El coloquio de los perros, por el contrario, el autor sí puso en solfa el entramado estético-ideológico de la picaresca en general y del Guzmán en singular. No me voy a detener en la contrafacción 
burlesca y crítica que efectúa el complutense del género, que ha sido bien estudiada por la crítica, sino en soslayar el ejercicio de historia literaria que realiza, que, al igual que en el Persiles con el de la épica amorosa en prosa, se manifiesta metadiscursiva e implícitamente.

Luego de contarle su desdichada experiencia matrimonial, el alférez Campuzano le ofrece al licenciado Peralta la lectura de unas páginas suyas en las que transcribió la conversación que mantuvieron dos canes cabe su cama mientras curaba la sífilis que de recuerdo le había dejado doña Estefanía de Caicedo. Los dos amigos discuten acaloradamente sobre la verdad y la mentira del manuscrito del alférez, cuando el licenciado, lector capacitado e inteligente, salta con lo de: “¡Cuerpo de mí! [...] Si se nos ha vuelto el tiempo de Maricastaña, cuando hablaban las calabazas, o el de Isopo, cuando departía el gallo con la zorra y unos animales con otros" (El casamiento engañoso, p. 536). Resulta, pues, que una vez más Cervantes se remonta hasta el origen de los tiempos, al disponer que la novela picaresca hunde sus raíces en las fábulas del contrahecho Esopo; si bien, más que en las palabras de Peralta, se echa de ver en el artificio de Campuzano de que dos perros hablen en animado coloquio. Y ello porque no se le escapaba que "a través de la escena fantástica de su mundo animal, la lección de la fábula se aplica, alegóricamente, al entorno real. A diferencia del cuento fantástico, las figuras de los animales parlantes no invitan a una evasión, sino a una meditación del entorno real" (García Gual, 2006: 11) ${ }^{20}$. Es decir, sabía que la fábula, como la picaresca, en especial el Guzmán, albergaba una indudable intención moral cuya admonición se cobraba bajo la fórmula sentencia-ejemplo o dramatización-moraleja. No obstante el aviso, la fábula clásica carecía de propósito satírico. Este alcanzó su difusión en la Antigüedad por medio de la filosofía cínica y la sátira menipea, cuyos ejemplos señeros no son sino los relatos y los diálogos de Luciano y El asno de oro (siglo II) de Apuleyo. “¿Al murmurar llamas filosofar? - le espeta Cipión a Berganza — ¡Así va ello! ¡Canoniza, canoniza, Berganza, a la maldita plaga de la murmuración!, y dale el nombre que quisieres, que ella dará a nosotros el de cínicos, que quiere decir perros murmuradores" (El coloquio de los perros, pp. 567-568). Por consiguiente, en El coloquio, Cervantes está vinculando a la escuela filosófica de Diógenes de Sínope con la obra literaria de Menipo de Gádara, mas a través del cuento milesio del africano y de la crítica mordaz del sirio. Y ello porque su novela-

${ }^{20}$ Recuérdese que Diego de Saavedra Fajardo, en la segunda redacción de su República literaria, ponía en boca de Heráclito un panegírico del fabulista griego en términos de filósofo: "Seguid a este esclavo llamado Isopo [le dice Heráclito a Demócrito] y veréis que, induciendo a hablar a aquellos animales, enseña por medio de ellos a esta república la verdadera filosofía moral y política, siendo los maestros más seguros y verdaderos que tiene. Esto, pues, oh, Demócrito, ¿es digno de risa u de perpetuas lágrimas en un filósofo atento al desvalimiento de nuestra humana naturaleza?" (2006: 272-273). 
coloquio se relaciona críticamente con las obras de transformación así como con la literatura lucianesca, de las cuales derivan las novelas picarescas: no en vano establece la ecuación cínicos-perros-pícaros ${ }^{21}$. Luciano y Apuleyo, en efecto, se habían servido de las metamorfosis hombre-animal, de las transmigraciones y de los sueños para, como los cínicos, satirizar y censurar a la sociedad de su tiempo; un empeño similar, sólo que a través de la perspectiva del pícaro, al de los escritores ocasionales del género picaresco.

Fue Erasmo, como bien se sabe, quien puso de moda en Europa al sofista de Samósata con sus traducciones, cuyo influjo se dejó sentir, y cómo, en el erasmismo y el humanismo españoles de la época del Emperador, tanto, que fue clave así para el Lazarillo como para otras obras de ficción: piénsese en la Segunda parte anónima de Amberes y el Crótalon (1552) de Cristóbal de Villalón, o de pseudoficción, como el estupendo Viaje de Turquía (¿1556?). Mas también para el espíritu barroco, como lo atestiguan Alemán, Quevedo y Gracián. El asno de oro de Apuleyo, por su parte, tuvo una feliz traducción al castellano en 1513 obra del arcediano Diego López de Cortegana, que no sólo fue fuente directa del Baldo (1542) en los episodios de Falcheto y Cíngar, sino también del Lazarillo, del Guzmán y del Buscón. Cervantes, que no se libró de su valimiento, en tanto que uno y otro, Luciano y Apuleyo, son fundamentales en el conjunto de su obra, los recoge en su bilogía. Bien es cierto que Luciano hace aparición de manera implícita, sobre todo por El sueño o El gallo, en función de su forma dialogada y por otros detalles menores, como las explicaciones concernientes a la transformación de Pitágoras en gallo que recuerdan a las que se dan Cipión y Berganza sobre su prodigioso don del habla, así como por la visión desencantada del mundo. También el Icaromenipo, donde Menipo y el Amigo, como Campuzano y Peralta, discuten sobre la veracidad del viaje a la luna del primero. En cambio, la obra de Apuleyo es citada expresamente por la Cañizares; de modo que El asno de oro tiene una presencia más activa: informa todo el conjunto, bien a través de la transformación de Lucio en asno, bien por la narración en primera persona, que acuerda con la de Berganza, bien por otros pormenores que llegan hasta el detalle más nimio pero revestido de honda significación, como el que Berganza, al igual que Lucio-asno, sea pelirrojo, y por tanto encarnación del pecado y de las fuerzas del mal, que sin embargo trascienden por gracia de la iluminación espiritual, al igual, y no es casualidad, que le ocurre a Guzmán.

El poder demoniaco, en la época clásica y en el Siglo de Oro, aunque desde una visión moral e ideológica diferente, está vinculado con la hechicería y la bru-

${ }^{21}$ Aunque podría ser no más que mera casualidad, no ha de despreciarse la posibilidad de que Cervantes, con sus perros habladores, hiciera alusión al apotegma de Licurgo que trae a colación Alonso de Barros, en el Elogio a la primera parte del Guzmán de Alfarache, "de los dos perros nacidos de un parto" (I, p. 116). Por otro lado, vid. Riley (2001c: 232-236 y 2001d). 
jería. Desde la Odisea se cuentan por decenas las obras antiguas que versan sobre el tema, cuyos hitos son tal vez la Medea de Eurípides; El viaje de los Argonautas de Apolonio de Rodas; el idilio II de Teócrito, más conocido como La hechicera o La farmacopea; la égloga VIII y la Eneida de Virgilio; la Canidia de Horacio; la novela helenística; y, por supuesto, las obras de Luciano, especialmente los diálogos Los cuentistas y Las cortesanas - también la Metamorfosis, aunque es de dudosa atribución-, y de Apuleyo, en cuya época, la Segunda Sofística, la literatura hermética, la superstición, la magia y las religiones orientales gozaron de amplísima difusión, contra la que reaccionan ambos escritores, sobre todo el escéptico sirio. Lógicamente tales textos, muy leídos la mayor parte, dejan su huella, entre otros, en La Celestina, que, como bien vio Lázaro Carreter (1978: 201), "anduvo siempre merodeando por el género [picaresco]". Cervantes supo ver esta ilación entre los textos clásicos ("las Eritos, las Circes, las Medeas" [El coloquio de los perros, p. 591]), el celestinesco y la picaresca, y lo dio forma en el diálogo y en la figura de la Cañizares y fondo en la lección de esta: "que seas bueno en todo cuanto pudieres; y si has de ser malo, procura no parecerlo en todo cuanto pudieres" (El coloquio de los perros, p. 597).

Octavio Paz (2000: 491-492), con su característica lucidez, escribió sobre las metamorfosis:

Apuleyo nos cuenta la de Lucio en Asno; Kafka, la de Gregorio Samsa en cucaracha. Conocemos el pecado de Lucio: su afición por la hechicería y la concupiscencia; ignoramos cuál fue la falta de Samsa. Tampoco sabemos quién lo castiga: su juez ni tiene nombre ni rostro. Convertido en asno, Lucio recorre la Grecia entera y le suceden mil cosas maravillosas, terribles o cómicas. Vive entre bandidos, asesinos, esclavos, terratenientes feroces y campesinos igualmente crueles; su lomo transporta el altar de una diosa oriental, servida por sacerdotes invertidos, ladrones y aficionados a la flagelación; varias veces está a punto de perder la virilidad, lo que no le impide tener amores con una señora rica, hermosa y ardiente; pasa temporadas de hambre y otras de hartura... A Gregorio Samsa no le ocurre nada: su horizonte son los cuatro muros sórdidos de una casa sórdida. A pesar de los palos, la salud jamás abandona al asno; la cucaracha está más allá de salud o enfermedad: su estado es la abyección. Lucio es sentido común y truculencias mediterráneos. Gastronomía y sensualidad teñida de sadismo; elocuencia grecolatina y misticismo. El Falo y la Idea. Todo culmina en la visión gloriosa de Isis, la madre universal, una noche frente al mar. Para Gregorio Samsa, el fin es la escoba doméstica que barre el suelo de su cuarto. Apuleyo: el mundo es visto y juzgado por un asno; Kafka: la cucaracha no juzga al mundo, lo sufre.

Pues bien, a medio camino entre estos dos polos, y mucho más ambiguo, ya que nunca sabremos si Cipión y Berganza fueron hombres metamorfoseados en animales o perros todo el tiempo, El coloquio, metanovela en la que se enjuicia, se repasa y se deconstruye el género picaresco y su historia literaria, no 
es, desde El casamiento engañoso, sino la mayor reivindicación cervantina de la literatura como ficción, como un ubérrimo acto de comunicación entre el escritor y el lector, en el que uno propone y el otro dispone. Broche de oro de una raccolta di novelle que se propone como ejercicio honesto, agradable y de goce intelectual y estético: "Sí que no siempre se está en los templos; no siempre se ocupan los oratorios; no siempre se asiste a los negocios, por calificados que sean. Horas hay de recreación, donde el afligido espíritu descanse" 22 . Pero que encierran una verdad no dada: "Heles dado nombre de ejemplares, y si bien lo miras, no hay ninguna de quien no se pueda sacar algún ejemplo provechoso; y si no fuera por no alargar este sujeto, quizá te mostrara el sabroso y honesto fruto que se podría sacar, así de todas juntas, como de cada una por sî" (Novelas ejemplares, p. 18).

\section{BIBLIOGRAFÍA}

Alemán, Mateo (1987): Guzmán de Alfarache, José María Micó (ed.), 2 vols., Madrid, Cátedra.

Asensio, Eugenio (2005): De fray Luis de León a Quevedo y otros estudios sobre retórica, poética y humanismo, Salamanca, Universidad de Salamanca.

Avalle-Arce, Juan Bautista (1990): "Cervantes entre pícaros", Nueva Revista de Filología Hispánica, XXXVIII, pp. 591-603.

Bataillon, Marcel (1973): "Relaciones literarias", en Juan Bautista Avalle-Arce y Edward C. Riley (eds.), Suma cervantina, Londron, Tamesis Books, pp. 215-232.

Blanco, Mercedes (2007): “El Quijote y el Guzmán: dos políticas para la ficción”, Criticón, 101, pp. 127-149.

Blanco Aguinaga, Carlos (1957): "Cervantes y la picaresca. Notas sobre dos tipos de realismo", Nueva Revista de Filología Hispánica, XI, pp. 313-342.

Blasco, Javier (2005): Cervantes, raro inventor, Alcalá de Henares, CEC.

Cabo Aseguinolaza, Fernando (1992): El concepto de género y la literatura picaresca, Santiago, Universidad de Santiago.

Castro, Américo (2002a): El pensamiento de Cervantes y otros estudios cervantinos. Obra reunida, pról. de J. Rodríguez-Puértolas, vol. I, Madrid, Trotta.

Castro, Américo (2002b): Cervantes y los casticismos españoles y otros estudios cervantinos. Obra reunida, pról. de F. Márquez Villanueva, vol. II, Madrid, Trotta.

\footnotetext{
${ }^{22}$ En el capítulo XXXII de la primera parte del Quijote, el cura Pero Pérez, ante la confusión del ventero entre la literatura de ficción y la histórica, sostiene que en "los libros de caballerías... todo es compostura y ficción de ingenios ociosos, que los compusieron para el efeto que vos decís de entretener el tiempo". El ventero, sin embargo, obcecado en sus trece, se defiende arguyendo que es imposible que libros que están impresos con licencia del Consejo Real sean mentiras disparatadas. El cura, entonces, dice unas palabras que semejan, en apoyo de la literatura como entretenimiento, a las del Prólogo de las Novelas ejemplares: "Ya os he dicho, amigo, que esto se hace para entretener nuestros ociosos pensamientos; y así como se consiente en las repúblicas bien concertadas que haya juegos de ajedrez, de pelota y de trucos, para entretener a algunos que ni tienen, ni deben, ni pueden trabajar, así se consiente imprimir y que haya tales libros, creyendo, como es verdad, que no ha de haber alguno tan ignorante que tenga por historia verdadera ninguna destos libros" (Don Quijote, I, XXXII, pp. 343-344).
} 
Cervantes Saavedra, Miguel de (1996): La Galatea. Obra Completa, Florencio Sevilla y Antonio Rey Hazas (eds.), vol. 1, Madrid, Alianza.

Cervantes Saavedra, Miguel de (1997): Viaje del Parnaso. Obra Completa, Florencio Sevilla y Antonio Rey Hazas (eds.), vol. 12, Madrid, Alianza.

Cervantes Saavedra, Miguel de (2001): Novelas ejemplares, Jorge García López (ed.), Barcelona, Crítica.

Cervantes Saavedra, Miguel de (2004): Los trabajos de Persiles y Sigismunda, Carlos Romero Muñoz (ed.), $5^{\text {a }}$ ed., Madrid, Cátedra.

Cervantes Saavedra, Miguel de (2005): Don Quijote de la Mancha, Martín de Riquer (ed.), Barcelona, Booket.

Close, Anthony (1990): "Algunas reflexiones sobre la sátira en Cervantes", Nueva Revista de Filología Hispánica, XXXVIII, pp. 493-511.

Close, Anthony (2007): Cervantes y la mentalidad cómica de su tiempo, Leticia Iglesias y Carlos Conde (trads.), Alcalá de Henares, CEC.

Cros, Edmond (2002): "Guzmán de Alfarache y los orígenes de la novela moderna", en Pedro M. Piñero (ed.), Atalayas del "Guzmán de Alfarache”, Sevilla, Universidad de Sevilla-Diputación de Sevilla, pp. 167-177.

Cros, Edmond (2005): "1599-1605: orígenes de la novela europea en España", en Christophe Couderec y Benoît Pellistrandi (coords.), "Por discreto y por amigo". Mélanges offerts à Jean Canavaggio, Madrid, Casa de Velázquez, pp. 397-404.

Dunn, Peter (1973): "Las Novelas ejemplares", en Juan Bautista Avalle-Arce y Edward C. Riley (eds.), Suma cervantina, London, Tamesis Books, pp. 81-118.

Forcione, Alban K. (1970): Cervantes, Aristotle and the "Persiles", Princeton, Princeton University Press.

Forcione, Alban K. (1984): Cervantes and the Mystery of Lawlessness: A Study of "El casamiento engañoso" y el "Coloquio de los perros", Princeton, Princeton University Press.

García de la Concha, Víctor (1981): Nueva lectura del "Lazarillo". El deleite de la perspectiva, Madrid, Castalia.

García Gual, Carlos (2006): intr. a Esopo, Fábulas, Pedro Bádenas de la Peña y Javier López Facal (eds.), Gredos, Madrid, pp. 7-26.

García López, Jorge (1999): "Rinconete y Cortadillo y la novela picaresca", Cervantes, XIX, $1^{\circ}$ fall, pp. 113-124.

Garrido Domínguez, Antonio (2007): Aspectos de la novela en Cervantes, Alcalá de Henares, CEC.

Gilman, Stephen (1993): La novela según Cervantes, Carlos Ávila (trad.), México, FCE.

Guillén, Claudio (1971): Literature as System: Essays Toward the Theory of Literary History, New Jersey, Princeton University Press.

Guillén, Claudio (1985): Entre lo uno y lo diverso, Barcelona, Crítica.

Guillén, Claudio (1988): "Luis Sánchez, Ginés de Pasamonte y el descubrimiento del género picaresco", en Claudio Guillén, El primer Siglo de Oro, Barcelona, Crítica, pp. 197-211.

Guillén, Claudio (2002): "Del Guzmán y los Guzmanes", en Pedro M. Piñero (ed.), Atalayas del "Guzmán de Alfarache", Sevilla, Universidad de Sevilla-Diputación de Sevilla, pp. 65-80.

Joly, Monique (1999): “Cervantes y la picaresca de Mateo Alemán”, en Jean Canavaggio (ed.), La invención de la novela, Madrid, Casa de Velázquez, pp. 269-276.

Lazarillo de Tormes (2011): Francisco Rico (ed.), Madrid, RAE-Galaxia Gutenberg.

Lázaro Carreter, Fernando (1978): "Lazarillo de Tormes" en la picaresca, Barcelona, Ariel.

Luciano de Samósata (1981): Relatos verídicos, en Obras I, intrd. general de J. Alsina Clotas, A. Espinosa (ed.) Alarcón, Madrid, Gredos, 1981, pp. 176-227.

Mann, Thomas (2006): Carlota en Weimar, Francisco Ayala (trad.), Barcelona, Edhasa.

Márquez Villanueva, Francisco (1995): "La interacción Alemán-Cervantes", en Francisco Márquez Villanueva, Trabajos y días cervantinos, Alcalá de Henares, CEC, pp. 241-297. 
Martínez Bonati, Félix (1995): El "Quijote" y la poética de la novela, Alcalá de Henares, CEC. Micó, José María (1987): introd. a Mateo Alemán, Guzmán de Alfarache, José María Micó (ed.), 2 vols., Madrid, Cátedra, t. I, pp. 15-78.

Muñoz Sánchez, Juan Ramón (2004): "El Amadís de Gaula como posible fuente de La Galatea", Nueva Revista de Filología Hispánica, LII, pp. 29-44.

Muñoz Sánchez, Juan Ramón (2008): "Los vírgenes esposos del Persiles: el episodio de Renato y Eusebia", Anales Cervantinos, XL, pp. 205-228.

Narváez de Velilla, Francisco (1993), El Diálogo intitulado el Capón, Víctor Infantes y Marcial Rubio (eds.), Madrid, Visor.

Niemeyer, Katharina y Meyer-Minneman, Klaus (2008): "Cervantes y la picaresca", en Klaus Meyer-Minnemann y Sabine Schlickers (eds.), La novela picaresca. Concepto genérico y evolución del género (siglos XVI y XVII), Madrid, Iberoamericana, pp. 223-262.

Núñez Rivera, Valentín (2002): Razones retóricas para el "Lazarillo". Teoría y práctica de la paradoja, Madrid, Biblioteca Nueva.

Oleza, Joan (1991): "Las comedias de pícaro de Lope de Vega: una propuesta de subgénero", en M. Diago y Teresa Ferrer (eds.), Comedias y comediantes, Valencia, Univeristat de València, pp. 165-188.

Paz, Octavio (2000): "Metamorfosis", en Octavio Paz, Corriente alterna, Obras Completas, Barcelona, Galaxia Gutenberg, t. II, pp. 491-492.

Paz Gago, José María (1995): Semiótica del "Quijote", Amsterdam, Rodopi.

Pérez de León, Vicente (2010): Cervantes y el "Cuarto misterio", Alcalá de Henares, CEC.

Redondo, Agustín (2005): "De Ginés de Pasamonte a Maese Pedro", en Agustín Redondo, Otra manera de leer el "Quijote", $2^{\mathrm{a}}$ ed., Madrid, Castalia, pp. 251-263.

Rey Hazas, Antonio (2002): "El Guzmán de Alfarache y las innovaciones de Cervantes", en Pedro M. Piñero (ed.), Atalayas del "Guzmán de Alfarache", Sevilla, Universidad de SevillaDiputación de Sevilla, pp. 177-217.

Rey Hazas, Antonio (2003): Deslindes de la novela picaresca, Málaga, Universidad de Málaga.

Ricapito, Joseph V. (1985): "Cervantes y Mateo Alemán, de nuevo", Anales Cervantinos, XXIII, pp. 89-95.

Rico, Francisco (1989): La novela picaresca y el punto de vista, $3^{\mathrm{a}}$ ed., Barcelona, Seix Barral.

Riley, Edward C. (1973): “Teoría literaria”, en Juan Bautista Avalle-Arce y Edward C. Riley (eds.), Suma cervantina, London, Tamesis Books, pp. 293-322.

Riley, Edward C. (1981): "Romance y novela en Cervantes", en Manuel Criado del Val (ed.), Cervantes. Su obra y su mundo, Madrid, Edi-6, pp. 5-14.

Riley, Edward C. (1989): La teoría de la novela en Cervantes, Carlos Sahagún (trad.), Madrid, Taurus.

Riley, Edward C. (1998): “Cervantes: Teoría literaria”, en el pról. a Cervantes, Don Quijote de la Mancha, Instituto Cervantes (ed.), Francisco Rico (dir.), Barcelona, Crítica, pp. CXXIXCXLI.

Riley, Edward C. (2000): Introducción al "Quijote”, Enrique Torner Montoya (trad.), Barcelona, Crítica.

Riley, Edward C. (2001a): "Una cuestión de género", en Edward C. Riley, La rara invención, María C. Llerena (trad.), Barcelona, Crítica, 2001, pp. 185-202.

Riley, Edward C. (2001b): "La novela de caballerías, la picaresca y la primera parte del Quijote", La rara invención, María Carmen Llerena (trad.), Barcelona, Crítica, pp. 203-215.

Riley, Edward C. (2001c): "Cervantes y los cínicos (El licenciado Vidriera y el Coloquio de los perros)", en La rara invención, María C. Llerena (trad.), Barcelona, Crítica, pp. 219-238.

Riley, Edward C. (2001d): "Los antecedentes del Coloquio de los perros", La rara invención, María C. Llerena (trad.), Barcelona, Crítica, pp. 239-253.

Ríos, Vicente de los (2006): “Análisis del Quijote”, en Antonio Rey Hazas y Juan Ramón Muñoz 
Sánchez (eds.), El nacimiento del cervantismo. Cervantes y el "Quijote” en el siglo XVIII, Madrid, Verbum, pp. 271-373.

Rodríguez, Juan Carlos (2001): La literatura del pobre, $2^{\mathrm{a}}$ ed., Granada, Comares.

Rodríguez, Juan Carlos (2003): El escritor que compró su propio libro, Barcelona, Debate.

Roncero López, Victoriano (2010): De bufones y pícaros: la risa en la novela picaresca, Madrid, Iberoamericana.

Ruffinatto, Aldo (2000): Las dos caras del "Lazarillo", Madrid, Castalia.

Ruffinatto, Aldo (2001): intr. a Lazarillo de Tormes, Aldo Ruffinatto (ed.), Madrid, Castalia, pp. 7-86.

Saavedra Fajardo, Diego de (2006): República literaria, Jorge García López (ed.), Crítica, Barcelona.

Segunda parte del Lazarillo (1988): Pedro M. Piñero (ed.), Madrid, Cátedra.

Sobejano, Gonzalo (1972-1975): "Un perfil de la novela picaresca: el pícaro hablador", en Studia hispanica in honorem Rafael Lapesa, Madrid, Gredos, 3 vols., t. III, pp. 467-485.

Sobejano, Gonzalo (1975): "El Coloquio de los perros en la picaresca y otros apuntes", Hispanic Review, XLIII, pp. 25-41.

Sobejano, Gonzalo (1976-1977): "De Alemán a Cervantes: monólogo y diálogo", Homenaje al Profesor Muñoz Cortés, 2 vols., Murcia, Universidad de Murcia, t. II, pp. 713-729.

Sobejano, Gonzalo (1978): "Sobre tipología y ordenación de las Novelas ejemplares", Hispanic Review, XLVI, pp. 65-75.

Williamson, Edwin (1991): "El juego de la verdad en El casamiento engañoso y El coloquio de los perros", en Asociación de Cervantistas (ed.), Actas del II Coloquio Internacional de la Asociación de Cervantistas, Barcelona, Anthropos, pp. 183-199.

Zimic, Stanislav (1996): Las "Novelas ejemplares" de Cervantes, Madrid, Siglo XXI.

Fecha de recepción: 28 de octubre de 2011

Fecha de aceptación: 28 de junio de 2012 